\title{
漂砂と堆積作用の繋がり-野積海岸の 底質環境変遷に着目して
}

\author{
関口 秀雄 1 ・山崎 秀夫 $2 \cdot$ 石田 真展 3 \\ 東 良慶 ${ }^{4}$ 原口 強 ${ }^{5}$ 細山田 得三 ${ }^{6}$ \\ 1フェロー会員 大阪市立大学客員教授 理学研究科（广558-8585 大阪市住吉区杉本3-3-138） \\ E-mail:h.sekiguch@gmail.com \\ 2近畿大学教授 理工学部（广577-8502 東大阪市小若江3-4-1） \\ 3 近畿大学大学院生 総合理工学研究科( ( 577-8502 東大阪市小若江3-4-1) \\ ${ }^{4}$ 正会員 大阪工業大学准教授 工学部（ (5 535-8585 大阪市旭区大宮5-16-1) \\ ${ }^{5}$ 正会員 大阪市立大学准教授 理学研究科（广558-8585 大阪市住吉区杉本3-3-138) \\ ${ }^{6}$ 正会員 長岡技術科学大学教授 工学部（率940-2188 長岡市上富岡町1603-1）
}

\begin{abstract}
外海に面する河口砂浜海岸（野積海岸）の底質環境変遷を把握するために，その基本要素すなわち堆積物 の容れもの（基盤），漂砂源及び漂砂営力に係る現地調查と資料解析を行った．砂浜部の地質調査による と, 泥岩質海食台が存在し, その上面深度は現汀線際で海面下約 $10 \mathrm{~m}$ である. したがって, 大河津分水通 水に先立ち, 恰好の堆積空間が準備されていたことになる. 漂砂営力の指標として, 波による地形変化の 限界水深を岸沖断面変化（藤井, 桐, 1999）から推定すると, 概水 9 mになる. 大出水時には沖合にまで堆 積物が運び込まれることから, 砕波帯内外と沖浜（水深30 m 60 m) で柱状コア採取を行い, 砂泥成層の 実相を検討するとともに, 大河津分水通水にともなう沖浜堆積層厚を推定した.
\end{abstract}

Key Words : beach progradation, muddy flood deposit, shelf sedimentation, wave-dominated coast

\section{1. 序論}

日本の砂浜海岸の多くは，河川供給土砂を本来の漂砂 源としている. しかし，流域開発や河川水の高度利用に ともない，汀線地形や底質環境は，低頻度の洪水時の堆 積物配分様式に依存寸る傾向が強まってきたように見受 けられる. とりわけ，大出水時には大量の堆積物が沖合 にまで運び込まれる ${ }^{1)}$. 一方, 漂砂が活発に生じるのは 砕波帯内であるとして, 海岸深浅測量の範囲は外浜にと どまることが多い，そのため，外浜と沖浜の底質環境や 海浜変形に関する知見のギャップを埋めることは必ずし も容易ではない.

悩ましいのは，沖浜の面積が一般に広大なことである。 そのため, 高度デジタル測深技術をもってしても, 海浜 変形に係る堆積物の貯留量変化を水深変化のトレンド成 分として精確に検出寸るには多大なエフォートが必要に なり，それが㲘案となる局面も少なくない. 水深変化に は表れにくい底質混合や酸化還元も，生態系と関わりの 深い海底境界過程である.

本研究では, 上述に鑑み, 沿岸堆積体のなりたちを探
り，長期海浜変形について洞察を深め得る場として，大 河津分水路の河口両翼に拡がる寺泊・野積海岸に着目し た（図-1）.

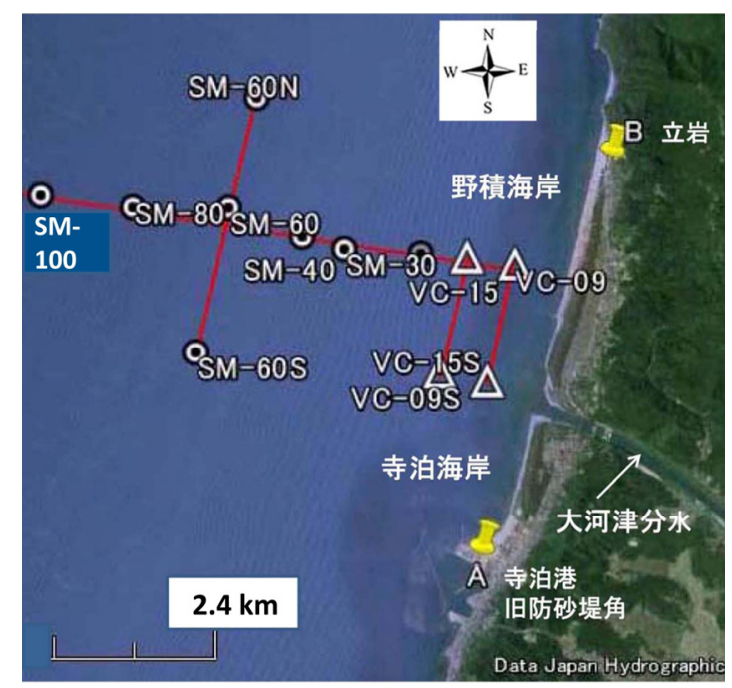

図-1＼cjkstart野積海岸における2015年海域調査の主要地点（背景は Google earthに基づく) 
具体的には，2011年7月新潟・福島豪雨出水を契機に 実施してきた現地調査結果等に基づいて，野積海岸の底 質環境変遷に焦点を当てる.

\section{2. 野積海岸における堆積環境調査の概要}

砂浜部において，現汀線に概ね直交する測線に沿って 計 5 本のコアボーリングを 2011 年〜2012 年に実施した. それらの平面位置を図-2 に示す．特筆す心゙きは，全て のコアボーリングにおいて泥岩質基盤を確認できたこと である．基盤上面の地形を図-3に示しておく。

沖合海域における主要な調査を列挙すると, 次のよう になる：外浜バイブロコアリング (2011，2013， 2015 年） ; 沖浜ピストンコアリング (2014 年，計 3 箇所 ; P30, P40, P60) ; Smith-McIntyre (SM) 式グラブ採泥（2015 年, 計 10 箇所; 水深 $21.3 \mathrm{~m} \sim 196 \mathrm{~m})$. 前出の 図-1 中 には，2015年バイブロコアリング地点（計 4箇所），及 びSM式グラブ採泥測線（水深約 $100 \mathrm{~m}$ 以浅のみ）を示 した. なお，ピストンコアリングの実施箇所は SM-30, SM-40, SM-60 地点の近傍である.

2015 年採取バイブロコア試料に対しては，X線 CT 撮 影を行い，堆積物の成層状況を詳しく調べた（後述）. 海底表層 SM 式グラブ採泥試料については, 船上でサブ コアを採取し，地球化学的分析等に供した．ピストンコ ア試料に対しては，環境指標として淡水生珪藻遺骸のコ ア内出現深度に着目した（後述）。

\section{3. 野積海岸の堆積環境の特徵}

\section{(1) 堆積体概観}

寺泊・野積海岸は元々は岩石海岸であり，大規模な流 入河川は存在しなかった. 後背丘陵の開削, そして大河 津分水路の通水開始（1922 年）にともない，信濃川流 域から大量の堆積物が河口を通じて海域に流入するよう になり，広大な砂浜が形成された ${ }^{2), 3)}$. 汀線前進の様子 を，野積海岸中央部を例にとって，図-2 に示す 4),5). 各 年代の汀線位置の同定には, 旧版地形図（1948 年を除 く計 5 図幅），1948 年米軍空中写真及び 2010 年 Google earth 衛星画像の GIS 解析が行われた ${ }^{4), 5)}$. ボーリング測 線との交点に着目すると, 同測線に沿う汀線位置の変化 を読み取ることができる. 1911 年汀線位置を $Y=0$ とお くと，1931，1948，1965，2010 年汀線位置は，それぞれ， $Y=8 \mathrm{~m}, 285 \mathrm{~m}, 415 \mathrm{~m}, 495 \mathrm{~m}$ になる.

大河津分水通水にともない，野積浜の断面地形はどの ように推移してきたのであろうか? 論点を図-3 に示す. 通水直前の海底面（旧海底面）については，泥岩質基盤

（海食台）が海底に露出していたとの前提のもとに，基 盤面を旧海底面とみなすことができる. 現海底面につい
ては直線 DD によってモデル化した．汀線位置は $Y=495$ $\mathrm{m}$, 海底勾配は，海域での測深結果（図-4 参照）をふ まえ 1/100 に設定している. 汀線前進モデル ${ }^{6), 7)}$ を援用 すると，各年代の汀線位置を既知として，対応する海底

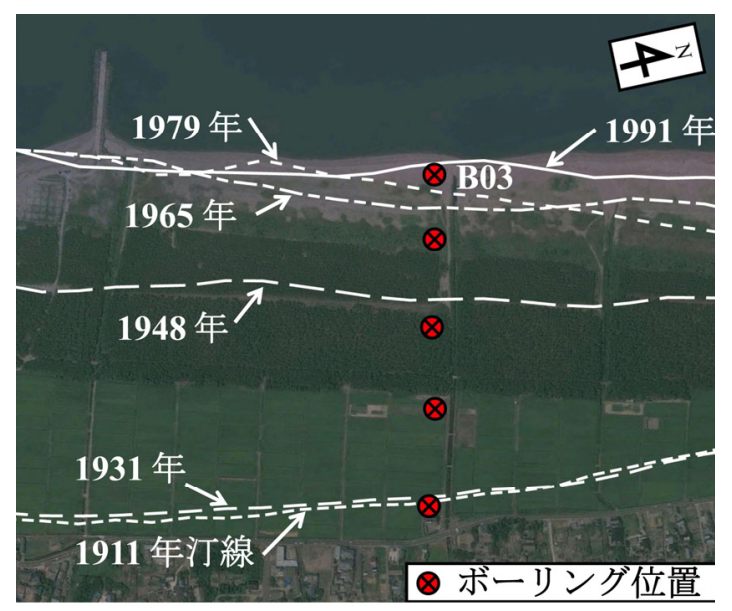

図-2＼cjkstart野積海岸における汀線変遷とコアボーリング位置（背景 は2010年 Google earth衛星画像)

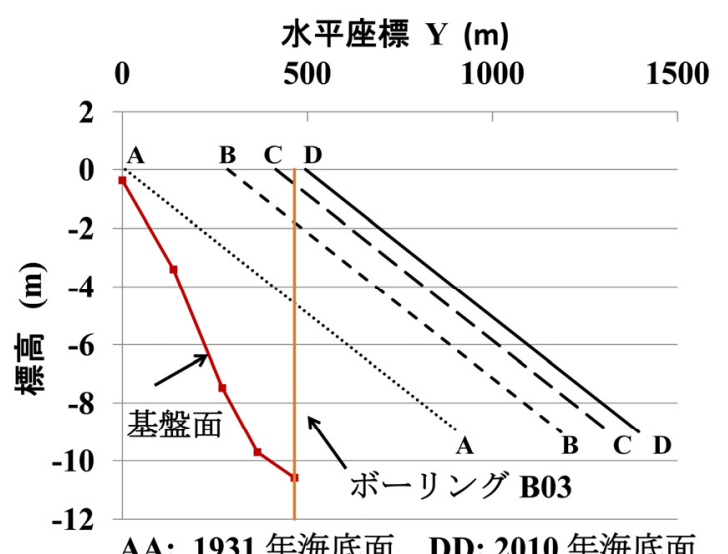

図-3 野積海岸における基盤面（海食台）と漂砂付加にとも なう砂浜地形発達

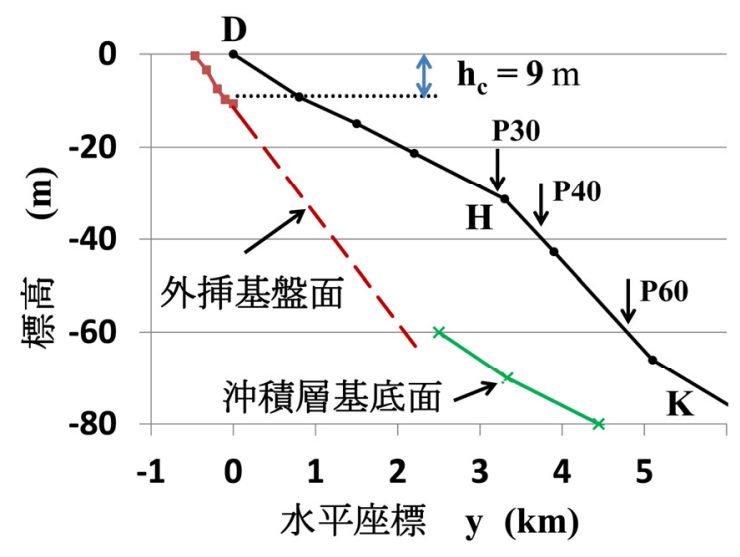

図-4 沿岸堆積体の概観 
面の推移を描くことができる. 図-3 中に，そのように して描いた 1931，1948，1965，2010 年海底面（直線群 AA〜DD）を示す．ここでは，基盤面と AA 面によって 境された空間に着目寸る. そこは，大河津分水通水以前 には海水によって占められていた潜在的な堆積空間であ る. 河川流出由来の堆積物が漂砂として流入するにとも ない，基盤に付加するかたちで，海中堆積体は次第に成 長していく.そして，ある段階になると，付加堆積体の 頂部は海面に顔を出す，その時期は 1931 年（もしくは その前後）であろう。したがって, 砂浜地形発達の初期 段階に当る 1922 年から 1931 年頃にかけては, 汀線位置 の変化には表れないかたちで，海浜変形（旧海底面への 漂砂付加による海中堆積体の成長）が進行していたとみ てよい.

上記の沿岸堆積体のスケールアップを試みる（図-4）。 現砂浜下の基盤（勾配約 1/43） は, 野積海岸沖の高分解 能音波探查(測線 E04)の結果 ${ }^{8}$ を参照すると，海面下 64 $\mathrm{m}$ 付近まで追跡できる. 現海底面については, SM 式グ ラブ採泥等の測深結果に基づいて離岸距離 $6 \mathrm{~km}$ まで を図示した（線分 DHK）。野積海岸沖の沖積層は意外 に厚い，沖積層基底面の等深度線図 ${ }^{9)}$ から読み取った結 果を図-4 に示寸（緑色の×印）。凸型傾斜変換点（地 点 $\mathrm{H}$ ）では，直下の沖積層厚は概ね $40 \mathrm{~m}$ に達寸る.

大河津分水通水以降の堆積作用を考えると，それは 沖積層最上部を形成する. 砕波帯内外の漂砂との関連を 視野に入れて, 次節では, 波による地形変化の限界水深 $\left(h_{c}\right)$ にいて検討する.

\section{(2) 漂砂営力の指標}

新潟沿岸域では毎年, 厳しい冬季風浪に曝される。一 例として, 新潟沖における月別最大有義波高の観測期間 平均值，最大值および最小值を図-5 に示寸．ここでは， 漂砂営力の指標として波による地形変化の限界水深 ${ }^{6), 7}$ に着目寸る. その背景には，波による地形変化の限界水 深と波候統計との繋がり ${ }^{10}$ がある（次式参照）。

$$
h_{c}=1.57 H_{e}
$$

ここに $H_{e}$ は有効波高である，その年間出現頻度は $0.14 \%$ (延べ時間にして 12 hours）と定義されている ${ }^{10)}$.

新潟沖の波候統計解析（永井 ${ }^{11}$ ，原著の表-7.9.1）に よると, 波高 $5 \mathrm{~m}$ 以上の出現頻度は $0.26 \%$ \%ある. そ こで, 式(1)の $H_{e}$ として $5 \mathrm{~m}$ を採用寸ると, 控えめな推 定值 $\left(h_{c}=7.9 \mathrm{~m}\right)$ を得る. この值は, 新潟海岸の深浅測量 実績の分析に基づく宇多 ${ }^{6}$ による推定值 $\left(h_{c}=8 \mathrm{~m}\right)$ と概祆 対応している.

野積海岸における波候統計は乏しく, 式(1)の適用を図 る段階には至っていない. しかし, 岸沖断面変化につい ては，藤井ら ${ }^{12}$ による観測結果が興味深い（図-6）。観
測時期は 1990 年, 1995 年〜1998 年のいずれも 3 月であ る. 図-6において, 最も沖側の砂州（頂部水深約 $4 \mathrm{~m}$ ) の形成位置を起点として沖側に目を向けていくと, 海底 面の鉛直変動幅が次第に減少していくことが分かる．水 深 $9 \mathrm{~m}$ 地点では，それら 5 本の海底曲線は実質的に収束 している. したがって, 野積海岸の波による地形変化の 限界水深は $9 \mathrm{~m}$ とみてよい.

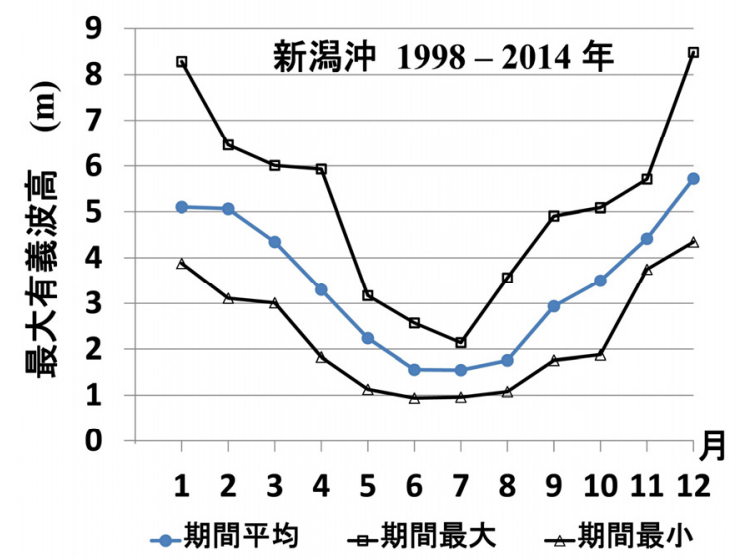

図-5 新潟沖の月別最大有義波高（NOWPHASに基づく）

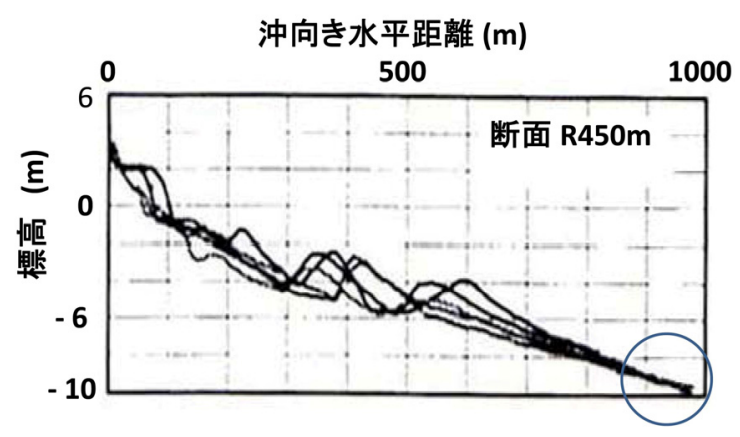

図-6＼cjkstart野積海岸における複数年の岸沖断面変化 ${ }^{12)}$

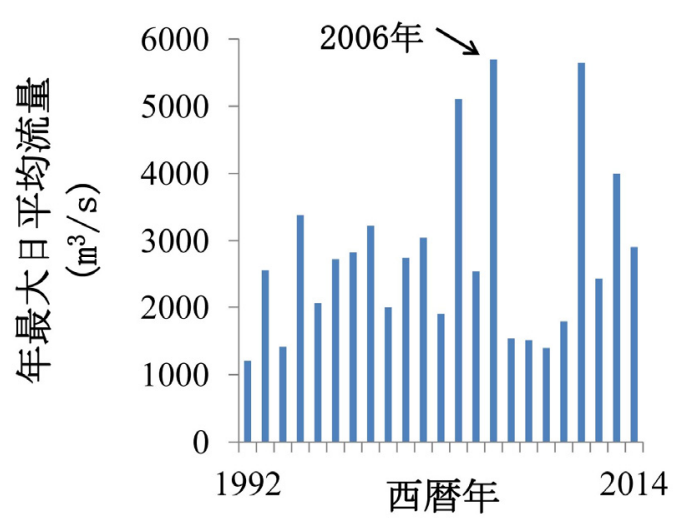

図-7 大河津分水路渡部観測所における年最大日平均流量の変 遷記録（国土交通省水文水質データベースに基づく） 


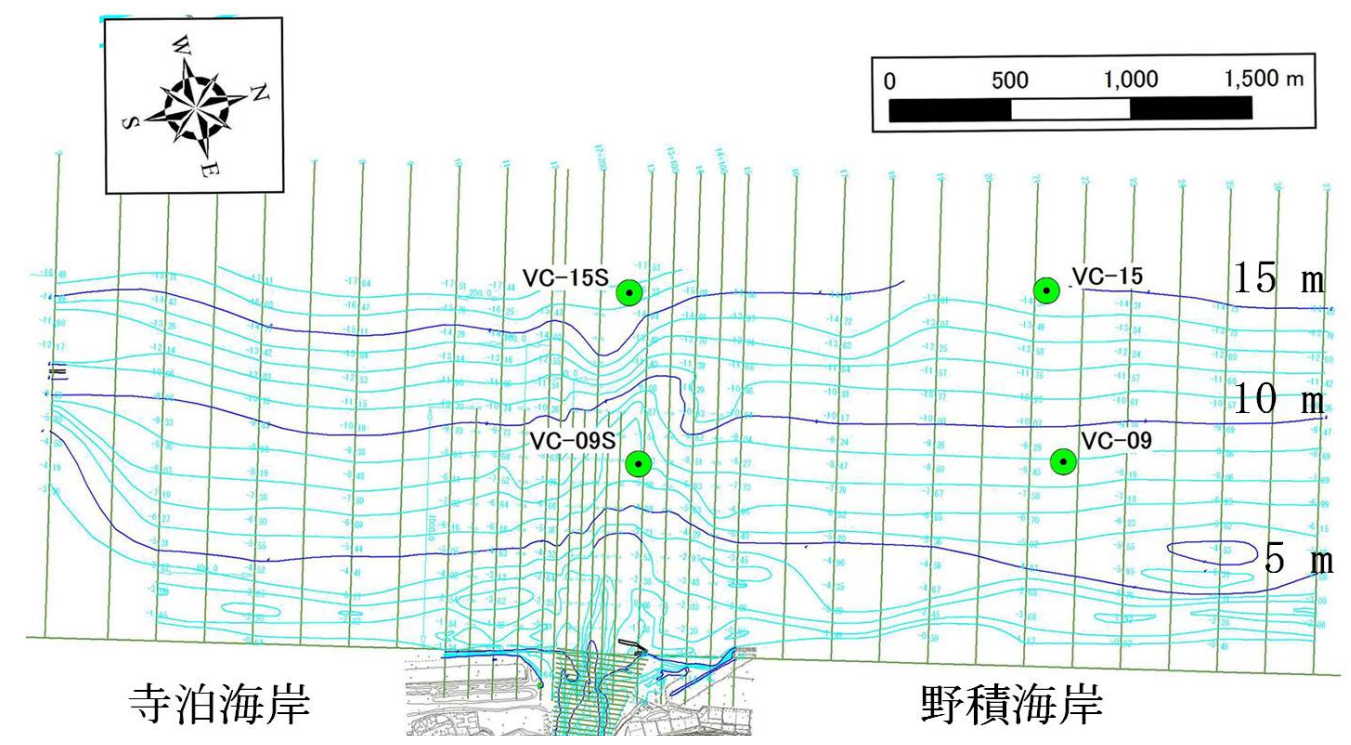

図-8２015年 8 月実施のバイブロコアリング位置 ; 背景図は 2008年 11 月信濃川河川事務所実施の深浅測量成果図

\section{(3) 大出水イベントによるインパクト}

信濃川流域で大出水が生じると, 低平な下流域（越後 平野）の治水安全のために大河津洗堰は閉じられ，洪水 は大河津分水路を通じて日本海に排出する. 最近 23 年 間の流況を図-7 に示寸. 2011 年 7 月新潟・福島豪雨出 水は記憶に新しい.

その 5 年前（2006年 7 月）には，梅雨前線にともなう 大出水が生じた．同年の総流砂量（固相質量ベース）を, 浮遊物質濃度 SS と日平均流量 Q $の$ 相関式にしたがって 見積もると ${ }^{13)}$ ，平年推算值（410万 ton/yr）の約 6倍にな る. 推算精度はさておき, 漂砂供給源として大出水の影 響が沖合にまで及ぶであろうことは想像に難くない（図 -8 参照）。同図において，大河津分水河口沖において 深度 $5 \mathrm{~m}$ の等深線のみならず, 深度 $10 \mathrm{~m}$ の等深線も沖 側に張り出していることに注目したい，波による地形変 化の限界水深 $(9 \mathrm{~m})$ を越えて, 沖合にまで堆積物輸送 が生じた証左の一例である。

2015年 8 月実施バイブロコアリング地点における砂泥 成層の実相については，次章に述べる.

\section{4. 野積海岸における底質環境変遷}

\section{(1) 砂浜前進にともなう上方粗粒化}

大河津分水通水にともなう堆積物の供給により, 野積 海岸の磯浜（海食台）は砂浜に変化した. 現汀線際のボ ーリングコア B03 の粒度組成には，その影響が反映さ れているはずである（図-9）。図中の曲線には細粒側ス パイク（泥の薄層の挟在）や，底層付近の粗粒ピーク (貝殼まじり砂質土の影響) が見られ，やや繁雑である. しかし, 大局的には標高 $-8 \mathrm{~m}$ 付近より上位では, 上方 に向かって粗粒化の傾向を示している.
なお，標高 $-5 m$ 付近や標高 $-2 m$ 付近にみられる粗 粒側スパイクについては，これらの層準において沿岸砂 州が形成されたと考えると, 砂浜前進にともなう堆積環 境遷移モデル (下部外浜 $\rightarrow$ 上部外浜 $\rightarrow$ 前浜遷移モデル) と矛盾しない。

\section{(2) 外浜における砂泥成層}

外浜の砂泥成層が重要なのは, 泥層を鍵層として流域 土砂流出の復元等の試みに拍車がかかるためである.

さて，2015年 8月採取バイブロコア試料の X線 CT濃 淡画像（各直交 2 断面）を，図-10 と図-11 に示寸。階 調処理パラメータとしては, 砂層と泥層を画像上で区別 するために，WL=1000 HU，WW=1600 HUに統一した. 輝度画像のもとになる物理量は, ボクセル $(0.5 \mathrm{~mm}$ 角) 毎の CT 数 (X 線線吸收係数の大きさを表す尺度) であ る ${ }^{14)}$. 本試料では, 海水で飽和した細砂層 : 1000〜1300 $\mathrm{HU}$; 海水で飽和した泥層： 600〜800 HU程度である.

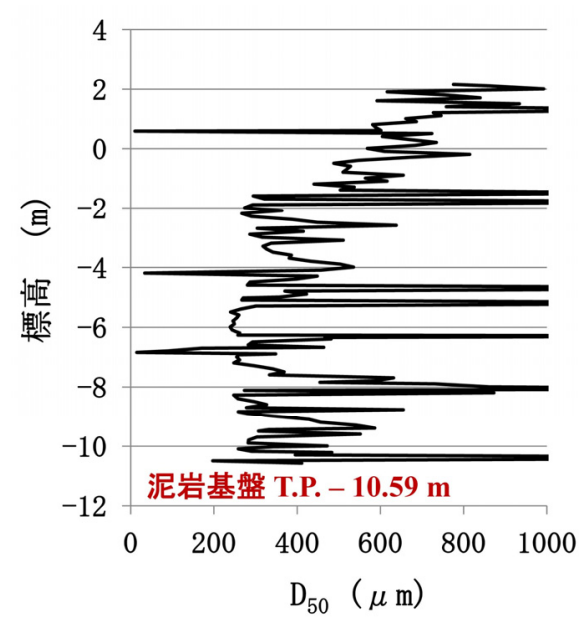

図-9 堆積物コア B03における中央粒径の鉛直分布 
CT画像上では，砂層は明るく，泥層は暗く見える. まず，野積海岸沖の VC-09コア（水深 9.2 m) の CT 画像（図-10(B)）に注目する. 全層にわたって明るく， 砂主体であることが分かる，仔細に見ると，泥粒から成 る薄層が深度 $31 \mathrm{~cm}$ 付近に存在する. 覆瓦状をなす複数 個の泥塊の存在（深度 $85 \mathrm{~cm}$ 付近 ; その直下にはひとき わ明るい湾曲層）も興味深い. 出水にともない一時的に 沈積した泥層がその後に侵食を受けた痕跡であろう。

大河津分水河口沖 VC-09S コアの CT 画像（図-10(A) では，砂泥成層の様子が明瞭である。同地点の水深は $6.2 \mathrm{~m}$ であり，㛜しい波浪擾乱を受けてきたはずである. それにもかかわらず，泥層はどのようにして保存された のであろうか?次のようなシナリオが考えられる：大 出水ピーク時には流水の作用により河口沖テラスにチャ ネル状凹地が形成される; 出水減衰期にはその凹地に 泥がゆっくりと沈積する ; 静穏波浪期を過ぎると漂砂 が活発になり，泥層を埋積する。

そのようにして泥層が保護されると，その下位砂層の 再移動は困難になることに留意したい. 実際, 地点 VC09S では，泥層の下位に中粒砂（深度約 $70 \mathrm{~cm} ９ 5 \mathrm{~cm}$ ) が「捕捉」されている. 砂浜涵養の機構からも注目に価 する事象である.

沖合の VC-15S 地点（水深 $17.2 \mathrm{~m}$ ) と VC-15地点（水 深 $14.9 \mathrm{~m}$ ）における砂泥成層は, 図-11 の CT 画像から 明らかである。ただし，いつ，どのようにして泥層が海 底面下約 $1 \mathrm{~m}$ 以深に形成されるに至ったかは不明である。 前述の河口沖テラス（VC-09S）の場合には，初期凹地 の形成を洪水流に帰した（あくまで想定であるが）。し かし, 沖合の水深約 15～17 m 地点に対しては，洪水流 の直接作用は想定し難い. 今後の研究課題である.

\section{(3) 大河津分水通水にともなう沖浜堆積層厚の推定}

野積海岸沖合の凸型傾斜変換点をまたぐ海域での堆積 特性を調べるために，2014年 8 月に重錘付自由落下方式 のピストンコアリングを実施した(P30，P40，P60 地点). 水深は，それぞれ，30 m, $40 \mathrm{~m} ， 60 \mathrm{~m}$ である(図-4参 照）. 異地性環境指標として淡水生珪藻遺骸に着目し, 検出個体毎にコア内出現深度を図-12に示した.

大河津分水通水以前には，同海域は河川流出の影響を 受けなかった. したがって，淡水生珪藻遺骸のコア内出 現深度は，大河津分水通水にともなう沖浜堆積層厚の増 加を反映する. 図-12 の結果によると，地点 P30 の淡水 生珪藻遺骸の最深出現深度は，現海底面下 $1.5 \mathrm{~m}$ である. したがって，同地点（現水深 $30 \mathrm{~m}$ ）における大河津分 水通水由来の堆積層厚は $1.5 \mathrm{~m}$ 以上，と推定することが できよう。

同様にして，地点 $\mathrm{P} 40$ と $\mathrm{P} 60$ に対しても大河津分水由 来の堆積層厚を推定することができる.

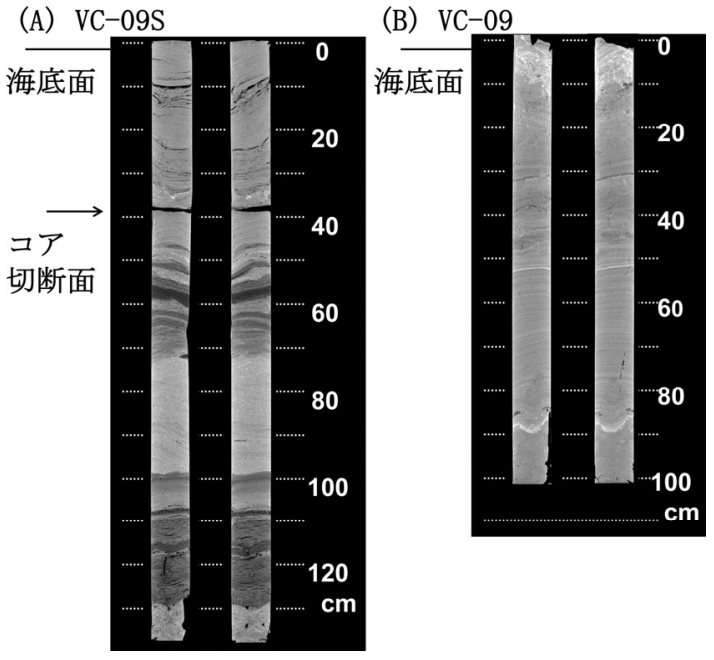

図-10 外浜堆積物コア (岸側) の X 線 CT 画像
(A) VC-15S

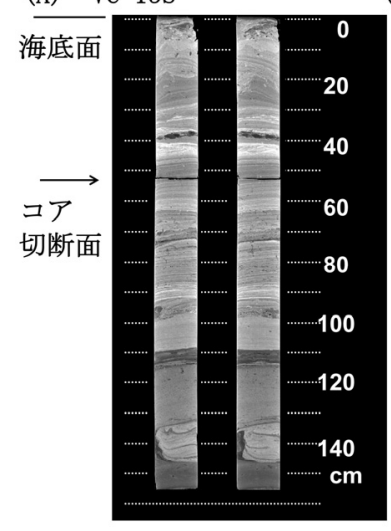

(B) $\mathrm{VC}-15$

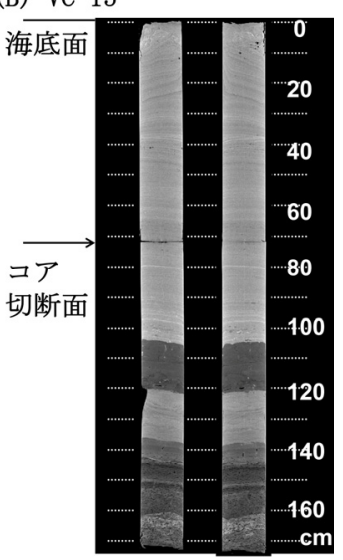

図-11 外浜堆積物コア (沖側) の X線 CT画像

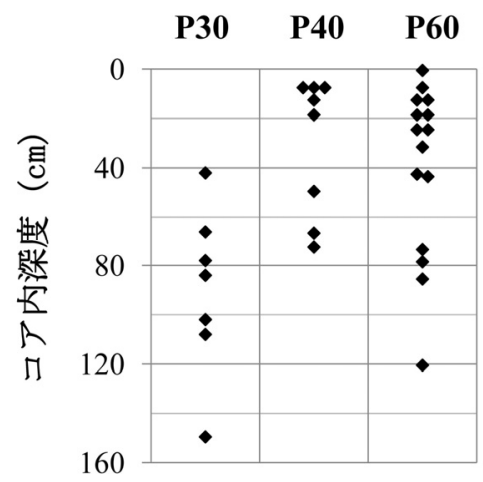

図-12 沖浜堆積物コア内の淡水生珪藻遺骸の出現深度分布

\section{5. 結論}

大河津分水河口に隣接する野積海岸に着目し, 外浜一 沖浜系の底質環境変遷を調べた. 得られた主要な結論を 
まとめると, 次のようである.

1) 大河津分水通水にともなう砂浜地形の発達に先立ち, 海食台という恰好の堆積空間が準備されていた.

2) 基盤面への漂砂付加による海中堆積体の成長様式と, 汀線前進の顕在化時期との間には繋がりがある.

3) 漂砂営力の指標として波による地形変化の限界水深 に着目し，野積海岸では概ね $9 \mathrm{~m}$ と推定した.

4) 砕波帯内外から採取したバイブロコア試料のX線 CT 画像に基づいて, 外浜の砂泥成層の実相を示した.

5) ピストンコア試料内の淡水生珪藻遺骸の出現深度分 布に着目し，大河津分水通水にともなう沖浜堆積層 厚は, 現水深 $30 \mathrm{~m}$ 地点で $1.5 \mathrm{~m}$ 以上になると推定し た. 長期的には無視し得ない浅海化の傾向である.

謝辞： 本研究に関連する資料を提供していただきま した国土交通省信濃川河川事務所，新潟県土木部，同長 岡地域振興局の関係各位に謝意を表します。バイブロコ ア採取とグラブ採泥には日本ミクニヤ(侏，ピストンコア リングと珪藻分析には復建調査設計(梀の協力を得ました. X線CT撮影には上田圭一博士（電力中央研究所）, CT 画像解析には吉永佑一博士（株防災地質研究所）の協力 を得ました. 野積海岸の岸沖断面観測につきましては, 藤井秀人教授（山形大学）より御教示をいただきました. 堆積物コア処理につきましては平石哲也教授（京都大学） に便宜を図っていただきました．本研究を遂行するに当 り, 科学研究費補助金（基盤研究(B), No. 23360206, No. 2689155, No. 26303004）のサポートを得ました。

\section{参考文献}

1) 関口秀雄, 山崎秀夫, 中川亮太, 石田真展, 東良慶, 原口強, 細山田得三: 河口砂浜海岸の堆積環境変遷 における洪水土砂流出の重要性, 土木学会論文集 B2 (海岸工学)，Vol. 69, No. 2, pp. I_691-I_695, 2013.

2) 磯部一洋 : 新潟県寺泊海岸における堆積過程につい て, 地質調査所月報, 第 29 巻, 第 12 号, pp. 773-792,
1978.

3) 土屋義人, 山下隆男, 斎藤正勝 : 河ロデルタの拡 大・縮小に起因する海浜変形（1）, 京都大学防災研 究所年報, 第 37 号 B-2, pp. 539-568, 1994.

4) 東良慶, 平石哲也, 関口秀雄, 河口海岸域における 砂浜地形の形成過程を読み解く試み, 土木学会論文 集 B1（水工学）, Vol. 69, No. 4, pp. I_1477-I_1482, 2013.

5) 東良慶, 田邊修平, 平石哲也, 関口秀雄 : 寺泊野積 海岸の河口砂浜域における淡水地下水流出量の推定, 土木学会論文集 B2（海岸工学）, Vol. 70, No. 2, pp. I_1211-I_1215, 2014.

6) 宇多高明 : 日本の海岸侵食, 山海堂, p. 442, 1997.

7) 栗山善昭 : 海浜変形, 技報堂出版, p. 157, 2006.

8) 井上卓彦, 木村治夫, 岡村行信 : 新潟沿岸域 20 万分 の 1 海底地質図説明書, 海陸シームレス地質情報, 新潟沿岸域, 数值地質図 S-2, pp. 1-24, 2011.

9）宮地良典，船引彩子, 楮原京子, 井上卓彦, 天野敦子, 卜部厚志, 岡村行信 : 越後平野沿岸部海域・陸域に 分布する沖積層の地層対比, 海陸シームレス地質情 報, 新潟沿岸域, 数值地質図 S-2, pp. 1-13, 2011.

10) Birkemeier, W.A.: Field data on seaward limit of profile change, J. Waterway, Port, Coastal and Ocean Engineering, ASCE, Vol. 111, No. 3, pp. 598-602, 1985.

11) 永井紀彦: 全国港湾波浪観測 30 力年統計(NOWPHAS 1970 - 1999), 港湾空港技術研究所資料, No.1035, p. 391, 2002.

12) 藤井秀人, 桐博英: 放水路周辺海浜の汀線変動とそ の要因，農業土木学会論文集，No. 200, pp. 35-43, 1999.

13) 関口秀雄, 山崎秀夫, 石田真展, 東良慶, 原口強, 細山田得三 : 大河津分水一寺泊野積海岸系における 河川土砂流出と堆積層形成の繋がり, 土木学会論文 集 B1（水工学），Vol。72，No. 4, pp. I_349-I_354, 2016.

14) Tanaka, A., Nakano, T. and Ikehara, K.: X-ray computer ized tomography analysis and density estimation using a sediment core from the Challenger Mound area in the Porcupine Seabight, off Western Ireland, Earth Planets Space, Vol. 63, pp. 103-110, 2011.

\title{
SEDIMENTATION ON A WAVE-DOMINATED SHOREFACE-AND-SHELF CONTINUUM AS AFFECTED BY RIVERINE FLOODS
}

\author{
Hideo SEKIGUCHI, Hideo YAMAZAKI, Masanobu ISHIDA, \\ Ryoukei AZUMA, Tsuyoshi HARAGUCHI and Tokuzo HOSOYAMADA
}

This paper explores the way in which an extensive sedimentary prism has formed on a marine abrasion platform and farther offshore, through the fluvial supply since 1922 onward. The major aspects of discussion include the following: rates of beach progradation; seaward limit of crosshore profile change on a wave-dominated shoreface; and impact of major floods that brought large quantities of sand and mud into and beyond the surf zone. The examination of sediment cores by X-ray computerized tomography (CT) clearly shows that the sandy deposits on the shoreface are intercalated with a series of muddy flood layers. Furthermore, the identification of freshwater diatom assemblies in columns of sediment retrieved from greater water depths (30 - 60 meters) enables the authors to estimate the rates of sediment accumulation on the inner shelf in the recent nearly 100 years. 